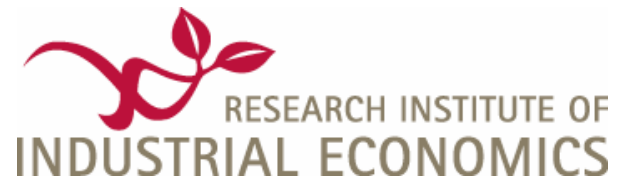

IFN Working Paper No. 668, 2006

\title{
Producer Prices in the Transition to a Common Currency
}

Niclas Andrén and Lars Oxelheim 


\title{
Producer Prices in the Transition to a Common Currency
}

\author{
Niclas Andrén \\ Institute of Economic Research, Lund University \\ PO Box 7080, SE-220 07 Lund, Sweden \\ Phone: +46-46-222 4666 \\ Fax: +46-46-222 4437 \\ Email: niclas.andren@fek.lu.se

\section{Lars Oxelheim} \\ Institute of Economic Research, Lund University \\ PO Box 7080, SE-220 07 Lund, Sweden \\ Phone: +46-46-222 8744 \\ Fax: +46-46-222 4437 \\ Email: 1ars.oxelheim@ffek.lu.se \\ and \\ The Research Institute of Industrial Economics (IUI) \\ PO Box 55665 SE-102 15 Stockholm, Sweden \\ Phone: +46-8-665 4527 \\ Fax: +46-8-665 4599 \\ Email: 1arso@iui.se
}




\title{
Producer Prices in the Transition to a Common Currency
}

\begin{abstract}
We analyze producer price developments in the transition from a national exchange rate regime to a monetary union. The focus is on the European Economic and Monetary Union (EMU). Stylized facts witness about an exploding gaps in producer-price inflation during the years immediately following the completion of the EMU. Price convergence is found to be an important driver throughout the entire euro period (1999-2005), but with no significant differences in speed compared to the pre euro period. Productivity growth had its primary effect in the first years and effective exchange-rate changes in the later years of the euro period.
\end{abstract}

Keywords: producer prices, relative prices, price convergence, euro, Balassa-Samuelson. JEL classifications: E31, E44, F15, F23, G34 


\section{Producer Prices in the Transition to a Common Currency}

Several recent studies have pointed out the deficiency of focusing on the cost of living index, the CPI, as the inflation target in monetary policy (see Kevin X. D. Huang and Zheng Liu, 2005). Typically, the CPI and the cost of production index, the PPI, exhibit quite different cyclical behaviors. As shown by Huang and Liu (2005), allowing for nominal rigidities at different stages of processing yields a situation where a Pareto-optimal allocation cannot be achieved and the central bank faces tradeoffs between stabilizing CPI inflation, PPI inflation, and the relative price between the two. This view on monetary policy is still rather novel in both policy and academic research, however, and there are no published results on the impact of changing exchange-rate regimes on the behavior of producer prices.

The focus of this paper is on the producer price development in the phase of transition from a national exchange-rate regime to a monetary union. A typical and timely example of great importance for monetary policy is the impact of the introduction of the common currency, the euro, in Europe. This is an unprecedented large-scale experiment in the reengineering of the rules of the game of monetary policy. Twelve countries made away of their individual currencies in favor of a common currency. ${ }^{1}$ Their central banks merged into one with a main objective of maintaining price stability in the euro area to safeguard the value of the euro. As for other central banks, price stability is measured in terms of the CPI. Empirical research has, without exception, focused on the impact of the euro on the cost of living in the euro area, in particular on the extent to which prices have tended to converge with the common currency. Since, as will be shown, producer prices have behaved quite differently from consumer prices we here ask the question; has the euro contributed to a convergence in producer prices in the euro zone? Our results pose challenges for the 
European Central Bank (ECB) if the aim of price stability were widened to include producer prices and relative prices.

Following Gros and Thygesen (1998) we date the beginning of the period of transition to the euro to August 1993 and our period of transition stretches up to December 2005. Between January 1999 and December 2005 (we denote this the post euro period), Irish producer prices in the manufacturing sector rose by 1.0 percent, while Portuguese manufacturing producer prices rose by 32.9 percent. $^{2}$ In contrast, the period of economic convergence from the end of the crisis of the Exchange Rate Mechanism (ERM) to the introduction of the euro (the pre euro period which we date from August 1993 to December $1998)^{3}$ exhibited a dispersion of producer-price inflation in the manufacturing sectors of the eleven original euro countries of -1.9 percent (Finland) to 13.1 percent (Italy). Not only are the figures substantially smaller in this period, but exchange-rate changes also compensated these inflation differences; expressed in ECUs, producer price inflation ranged from -1.2 percent (Austria) to 8.6 percent (Finland). The increasing dispersion in extreme developments is not an isolated observation; the standard deviation of cumulative producer-price changes among the eleven countries was 8.9 percent over the post euro period, whereas it was 3.3 percent (in ECUs) over the pre euro period.

These stylized facts admittedly only provide a piece of the puzzle towards understanding the impact of the euro - if any - on the behavior of manufacturing producer prices. Still, they suggest that relative producer-price developments have changed both in character and magnitude. This becomes even more obvious when compared to developments in consumer prices. Consumer-price developments were more stable than producer prices in the post euro period (s.d. 5.7 percent for changes in the harmonized index of consumer prices (HICP)), but at par with producer prices in the pre euro period (s.d. 4.2 percent). ${ }^{4}$ Relative prices of intermediate goods to final goods (PPI/CPI), or the real marginal cost as Huang and 
Liu (2005) denote them, clearly reveal differences in producer and consumer price developments. In the pre euro period, cumulative relative-price changes ranged from -3.9 percent (Italy) to -9.6 percent (Ireland) with a standard deviation of 1.7 percent, whereas in the post euro period they ranged from 12.7 percent (Portugal) to -21.4 percent (Ireland) with a standard deviation of 9.3 percent. $^{5}$ As these stylized facts show, consumer prices are not representative for producer prices.

The Irish "euro" experienced 31.6 percent real depreciation relative to the Portuguese "euro" over the seven-year post euro period with a common currency. Judging from this snapshot of price developments, Portuguese manufacturers have either taken a severe blow from Irish competition (to the extent Irish and Portuguese manufacturers are actually competing), or have experienced the golden days of excess profits (from increasing output prices in less than perfect product markets). To add perspective, over the same period unit labor costs fell by 10.5 percent in Ireland and rose by 14.6 percent in Portugal. Part of the Portuguese price increases could thus be the result of cost-plus pricing, but there is an unexplained component that could either be a source of lost competitiveness or of increasing profitability. Production volumes supply further hints; Portuguese production rose by 6.5 percent over the post euro period, compared to an increase of 53.8 percent in Ireland. Perhaps Portuguese manufacturers did not experience excess profits, after all? Irish manufacturers, on the other hand, seem to have experienced a combination of growing production volumes, productivity, and profit margins.

An important argument behind the introduction of a common currency was that the euro would work as a vehicle for increased transparency and elimination of legal and institutional trade barriers in the euro area. As part of this, the introduction of the euro was expected to eliminate macroeconomic trade barriers (Maurice Obstfeld and Kenneth Rogoff, 1995). The first few years with the euro have seen historically large spreads across countries in producer- 
price based real exchange and real interest rates making the elimination of macroeconomic trade barriers an issue of the producer-price development.

As to our results, we find strong support for price convergence, even after controlling for other factors influencing producer prices. However, price convergence is equally significant before and after the introduction of the euro and we do not find any specific effect at the time of the introduction of the euro. We also find productivity growth and changes in the effective, trade-weighted "national" euro to influence prices, causing a shift in the behavior of producer prices. Their relative influence exhibits inter-temporal differences.

The paper is organized as follows. In Section I we review arguments for and against an impact of the euro on producer prices and contrast them with prior empirical findings on consumer prices. Section II describes the data and presents stylized facts about the relative producer-price developments in the euro area in 1994-2005. In Section III, we discuss the methodology used. In Sections IV and $\mathrm{V}$ we perform our empirical testing of price convergence and the impact of other potential explanatory factors. We also discuss and test the robustness of our results. Section VI provides concluding remarks and policy implications of our findings.

\section{Why Might the Introduction of the Euro Influence Producer-price Developments?}

We argue that there are factors that in addition to or via price convergence can cause a link between the introduction of the euro and producer-price development. Below we will discuss them one by one. 


\section{A. Price Transparency}

If the introduction of the euro increases price transparency, countries with initially low prices would, according to the law of one price, experience relatively higher inflation than high-price countries during a transition period. This explanation assumes that corporate managers suffer from money illusion arising from expressing prices in different currencies. Psychological experiments by Thomas Mussweiler and Fritz Strack (2004) show that the euro was beneficial to consumers in this respect, but whether this also was the case for corporate managers is still an open question. From a producer viewpoint, reduction of money illusion would reveal itself as reduced possibilities to price to market. There is a supply-side story here as well. Elimination of money illusion could result in producers redefining their home market from the domestic market to the euro market. Since pricing to market is positively related to the relative size of the foreign market (Michael M. Knetter, 1993; Jiawen Yang, 1998), the result would be more uniform pricing across the euro zone (George M. von Furstenberg, 2003).

A common currency also contributes to price transparency by eliminating exchange-rate fluctuations. Exchange-rate fluctuations have been found to be detrimental to trade (see, for example, Pinelopi K. Goldberg and Michael M. Knetter, 1997; Rickard Friberg, 2001). Given nominal price rigidities, elimination of fluctuations in nominal exchange rates reduces relative-price volatility. Stabilized relative prices can be expected to lead to price convergence, for at least two reasons. Firstly, studies have shown pricing to market to increase with exchange-rate volatility (see von Furstenberg, 2003 and Michael B. Devereux et al, 2003 for reviews and analyses of economy-wide implications). This effect comes through several venues, not least due to foreign firms hedging - and passing through ensuing costs exchange-rate risk. Secondly, exchange-rate stability may increase trade (Maurice Obstfeld and Kenneth Rogoff, 2000; Andrew K. Rose, 2000), which in turn could reduce price differences (John McCallum, 1995; John F. Helliwell, 1996; Charles Engel and John 
H.Rogers, 1996). So far, experience seems to fulfill parts of these expectations. David Barr et al (2003) and Alejandro Micco et al (2002) find that the introduction of the euro increased trade within the euro zone by some $10-30$ percent during the first three years of its existence. ${ }^{6}$ This is a strong trade impact from the monetary union compared to previous waves of economic integration in the EU (Karen-Helen Midelfart et al, 2003). ${ }^{7}$

\section{B. Economic Convergence and the Balassa-Samuelsson Effect}

A large literature has investigated economic convergence and found convincing evidence that low-productivity countries have the ability to grow faster than productivity leaders under certain conditions, in particular under trade liberalization (for example, William J. Baumol, 1986; Xavier X. Sala-i-Martin, 1996; Farhad Rassekh, 1998). The inference is that trade impacts of the euro could be expected to promote further economic convergence within the euro zone. Matthew Canzoneri et al (2002) analyze productivity trends and real exchange rates in Europe between 1973 and 1997. They conclude that if productivity trends over this period were to continue in the post euro period, euro-zone countries would exhibit trend CPI inflation between -1 percent and 2 percent from the EMU average. von Furstenberg (2003) discusses the potential for productivity-growth differentials in the euro zone at length and concludes that remaining catching-up potential when the euro was introduced could be expected to be a source of extra nontradables inflation. ${ }^{8}$ In a Balassa-Samuelson (B-S) world, countries experiencing high growth and accompanying productivity increases would experience wage-driven price increases in nontradables sectors, which would show up as real appreciation when calculating real exchange rates using aggregate price indexes. This would be reinforced if tastes are nonhomothetic and biased towards superior nontradables, because the increasing incomes that accompany the catching-up process would lead to a demand- 
driven upward pressure on nontradables prices (Peter Neary, 1988; Jeffrey H. Bergstrand, 1991; Ronald MacDonald and Cezary Wójcik, 2004).

\section{The Composition of the Effective Trade-weighted Exchange Rate}

The composition of the euro currency basket differs from each member country's effective, trade-weighted exchange rate. This means that a given change of the euro influences prices differently in the member countries (Patrick Honohan and Philip R. Lane, 2003). ${ }^{9}$ Even if absolute purchasing power parity were to hold perfectly for each country we would see differential inflation rates due to differing levels of pass through of exchange rate changes by foreign exporters, as long as product baskets used to measure relative price levels differ. This means that ECB's monetary policy-making will, by construction, be suboptimal; safeguarding the value of the euro will yield different results across countries depending on each country's extra-euro-area exposure.

\section{About the Drivers}

To summarize, increased price transparency, elimination of exchange-rate fluctuations and ensuing increases in trade and economic convergence could be expected to lead to converging price levels. This would show up as divergent inflation rates during the transition period. In addition, differential imports of inflation could lead to differential - not necessarily converging - price developments, which would show up as divergent inflation rates in periods of asymmetric economic developments. The sources of dispersion of producer-price developments are of importance to economic policy as well as corporate competitiveness. Inflation differentials stemming from price convergence would be harmful to competitiveness, with producers in previously segmented high-price markets suffering from low-price 
competition. By contrast, a rise in inflation stemming from economic convergence would be neutral to the extent that it only derives from price increases of nontradables.

\section{E. Findings in Prior Research}

While no studies of the relationship between producer prices and the introduction of the euro have been published so far, a handful of studies have investigated the impact of the euro on consumer prices. Charles Engel and John H. Rogers (2004) find large reductions in consumer price dispersion across countries between 1990 and 1994, especially for tradables, and small but significant increases in price dispersion between 1998 and 2003. Alberto E. Isgut (2004) and David C. Parsley and Shang-Jin Wei (2001) show that sharing currency significantly reduces consumer price dispersion, whereas belonging to the same regional trading area does not. Isgut (2004) finds the effect of the euro per se in reducing consumer price dispersion to be significant. Pinelopi K. Goldberg and Frank Verboven (2004 and 2005) study the impact of the euro on car prices and find a small but significant decline in price differentials in the euro zone after the euro was introduced. Guenter Beck and Axel A. Weber (2001) find that the importance of borders on relative-price volatility has decreased substantially after the euro, though they still remain significant, whereas Hisham S. Foad (2005) finds that the importance of borders has not changed after the euro.

A few studies have instead modeled the impact of the euro on real exchange rate developments in the euro zone. Kees G. Koedijk et al (2004) find evidence of mean reversion of real exchange rates for a sample of nine euro-zone countries after 1992. The introduction of the euro did not increase the speed of mean reversion, however. They conclude that half-lives differ across countries. Maria-Dolores Gadea et al (2004) investigate real exchange rates of the euro countries against the dollar and find support for purchasing power parity (PPP) during the post Bretton-Woods period up to 1996; when extending the period up to 2001, they fail to find support for PPP. Daniele Antonucci and Alessandro Girardi (2006), using error- 
correction modeling of PPP, find the EMU, with the exception of Spain and Ireland, to be an integrated area. They fail to find any impact of the euro.

The empirical support of the B-S effect is inconclusive. Hans-Werner Sinn and Michael Reutter (2001) and von Furstenberg (2003) conclude, for consumer prices, that the B-S effect is an important driving force behind observed relative-price changes in Europe. Engel and Rogers (2004) find a more pronounced price convergence for nontradables than tradables in the early 1990s, which they interpret as a result of real-income convergence rather than reductions in restrictions in trade. Their empirical testing does not provide support for this interpretation, however. Isgut (2004) and John H. Rogers (2004) find a positive relationship between GDP per capita dispersion and price dispersion, as suggested by B-S. Rogers (ibid) finds a negative relationship between productivity growth and annual inflation, whereas Honohan and Lane (2003) find no relationship. Honohan and Lane (ibid) further show that the average euro-zone consumer-price inflation rate, as well as the inflation rates of the individual euro-zone countries, closely follows movements in nominal effective euro developments.

\section{Data}

We investigate developments in producer prices for the manufacturing sector (industry category D, ISIC revision 3), using data from the OECD Main Economic Indicators Database (vol 2005, release 02, series $045 \mathrm{~K}$ ) for ten of the eleven original euro countries (excl Luxembourg). ${ }^{10} \mathrm{~A}$ key issue when investigating price convergence is access to comparable price-level data. To be completely comparable, the composition of producer-price indices for different countries should be harmonized so as to measure price developments of the same goods and services. Harmonized producer-price indices do not exist, which means that the indices we use are not completely comparable across countries. This is a weakness of studies of producer prices, but a weakness shared by all price studies not using harmonized price 
indexes. Still, manufacturing producer prices are commonly used as proxies for prices of tradable goods (see, for example, Bill Alterman, 1997).

\section{A. Calibrating Producer Price Levels}

In order to improve comparability we calibrate producer price levels across the euro zone. To the best of our knowledge, the only large-scale producer-price level dataset available is the University of Groningen International Comparisons of Output and Productivity (ICOP) Database. It provides unit value ratios (UVRs) for the manufacturing sector. UVRs are bilateral purchasing power parities relative to the US for manufacturing outputs, calculated on matched (relative to the US) samples of products, with the sample of products varying between country pairs. The number of sample products is relatively small, generally about a few hundred, and covers only about 20 percent of manufactured output (Bart van Ark, 1993). Still, UVRs tend to be representative of manufacturing producer prices (Mary O'Mahony, 1996). UVRs are also regularly used by the International Labour Office as part of their key indications of the labor market. UVRs have been used extensively in productivity comparisons, not least in the detailed analysis of EU productivity and competitiveness published by the DG Enterprise of the European Commission in 2003 as part of their program on analysis of competitiveness (Mary O’Mahony and Bart van Ark, 2003). UVRs are for 1997 and expressed in ECU, and we use them to recalibrate each country's monthly manufacturing PPI series (expressed in ECU in the pre euro period and euro thereafter). UVRs are missing for Luxembourg, why we have to exclude this country from the testing.

In Table 1, that presents relative UVRs for our sample countries relative to Germany, we include for comparison relative unit labor costs (ULC), relative hourly compensation costs (HCC), and expenditure PPPs. Relative price levels differ quite extensively depending on which price measure is used. Correlations between the different measures range from 0.00 
(UVR and ULC) to 0.88 (HCC and EPPP). The zero correlation between UVRs and ULCs suggests a complete lack of relationship between price levels and labor costs. A high correlation (0.61) between UVR and HCC suggests that price levels rather reflect actual than productivity-adjusted labor costs. The correlation between UVR and EPPP is also found high (0.74), showing a close correlation between output prices in the manufacturing sector and sales prices to consumers.

\section{Insert Table 1 about here}

The price divergences exhibited in the table as of 1997 might seem strange, given the political negotiations preceding the introduction of the euro. However, it seems to be common practice by countries opting for fixed exchange rates to choose fixings at undervalued rates (von Furstenberg, 2003; Laszlo Halpern and Charles Wyplosz, 1997; Lars Oxelheim, 1996). As stated by von Furstenberg (2003:523), “[j]oining a multilateral monetary union, such as EMU, at an intentionally biased exchange rate is far more difficult and group-constrained than building in an initial bias when fixing the exchange rate unilaterally. Yet, small developing countries appear to have been given some leeway with regard to the choice of entry rate, even though multilateral negotiations were required."

\section{B. Producer Price Development in the Euro Zone - 1993-2005}

Figure 1 and Table 2 show that the spread between highest and lowest producer prices has dropped rather stably over the pre and post euro periods; in relative terms, the minimum price level increased from 62 percent to 74 percent of the maximum price level. This is one indication of converging prices. During the same time, the standard deviation of euro zone price levels fell from 15.1 percent to 9.4 percent. This change is significant at the 10 percent

level, which suggests that the euro countries have experienced $\sigma$-convergence. ${ }^{11}$ Much of the 
convergence, both in terms of reduced maximum spread and dispersion took place during the post euro period (the minimum price level was 67 percent of the maximum in December 1998 and the dispersion was 12.8 percent).

Insert Figure 1 about here

Insert Table 2 about here

Turning to individual countries in the post euro period, the Portuguese-Irish divergence in producer-price inflation discussed in the introduction is extreme, but not unique. The two countries with the second largest and smallest price increases were the Netherlands (cumulative price increase of 25.9 percent) and France (6.7 percent). This divergence amounts to 18.0 percent real depreciation of the "French euro" to the "Dutch euro", or 2.4 percent per annum. Prices rose sharply in most countries in the early post euro period. In fact, annual price changes reached levels not seen since the early 1980s. This early period of price increases lasted between 1.5-2 years. From then on, prices have been more stable (though with a slight increase in inflation towards the end of the sample period); annual inflation rates observed during 2001-2003 fell to historically low levels, comparable to rates seen just prior to the introduction of the euro.

The pre euro period was characterized by monetary convergence in the run-up to the EMU and inflation rates were low and fairly stable. During this convergence period, the maximum spread in cumulative producer-price changes, in local currency, was 12.5 percentage points. Due to accommodating exchange-rate changes, the maximum spread in producer-price changes, when expressed in EUR, was only 9.8 percentage points, reflecting an effective price decrease of -1.2 percent in Austria and an effective price increase of 8.6 
percent in Finland, that is, a real depreciation of the Austrian schilling relative to the markka of 10.0 percent, or 1.8 percent per annum.

Figure 2 shows a negative correlation between the initial price level and subsequent price changes. Producer prices have tended to converge over both periods, with countries with the lowest initial price levels having experienced the largest price increases. Also, the downward slope of the trend line for the post euro period is greater than for the pre euro period.

\section{Insert Figure 2 about here}

To summarize, producer-price inflation shows considerable swings. Still, we find relative producer-price developments after the introduction of the euro contrasting to the expectations formed by the EU-view on the role of the euro in elimination of barriers to competition.

\section{Methods}

The main approaches to convergence analysis are absolute and conditional $\beta$-convergence and $\sigma$-convergence (see Sala-i-Martin (1996) for a detailed exposition and Danny T. Quah (1996) for a critique). Absolute $\beta$-convergence prevails when low-price countries tend to experience higher inflation than high-price countries and the trend is towards complete elimination of any price differences. If our expectation of price convergence is correct then convergence in inflation rates (in the phase of transition) would be a logical impossibility. Let $\pi_{i, t, t+T} \equiv$ $\log \left(p_{i t+T} / p_{i, t}\right) / T$ be country $i$ 's annualized cumulative inflation rate between $t$ and $t+T$, and let $\log \left(p_{i, t}\right)$ be the logarithm of the country's price level at time $t$. We can then test for absolute $\beta$-convergence using a cross-sectional regression, 
(1) $\pi_{i, t, t+T}=a+b \log \left(p_{i, t}\right)+\varepsilon_{i, t, t+T}$

where $b<0$ will be an indication of absolute $\beta$-convergence. The speed of convergence is then given by $|\beta|$ in $b=\left(1-e^{-\beta T}\right) / T$. $\beta$ can also be estimated directly using nonlinear least squares,

$\left(1^{\prime}\right) \quad \pi_{i, t, t+T}=a+\left(1-e^{-\beta T}\right) / T \log \left(p_{i, t}\right)+\varepsilon_{i, t, t+T}$

where $\mathrm{T}$ is the length of the sample period in years. This will in addition yield standard errors for the speed of convergence. Under the null hypothesis of no convergence, $\beta$ is equal to zero. In this case, a shock to $p_{i, t}$ is permanent. The half-life of a shock to $p_{i, t}$ is given by $-\ln (2) / \ln (1+\beta)$

One weakness of absolute $\beta$-convergence is its implicit assumption that all countries converge to the same price level. This is highly implausible, given that we are considering prices of traded and non-traded goods and services. For example, in a B-S world, a country experiencing high growth would see its price level increasing, even if prices of tradables are completely converged. This means that we would expect different countries to be converging to different price levels. This is the concept of conditional $\beta$-convergence. We test this by estimating

(2) $\pi_{i, t, t+T}=a+\left(1-e^{-\beta T}\right) / T \log \left(p_{i, t}\right)+\gamma \mathbf{X}_{i, t}+\varepsilon_{i, t, t+T}$

where $\mathbf{X}_{i, t}$ is a set of conditioning variables. If $\beta<0$ even after including $\mathbf{X}$, we see evidence of conditional $\beta$-convergence. This is, with some variations in the exact specification, the 
methodology employed by most prior studies of convergence in consumer prices (see, for example, Honohan and Lane, 2003; Engel and Rogers, 2004).

Due to the short period with the euro, employing (1') or (2) on the euro zone means having to work with small samples and being forced to use non-parametric regressions. An alternative is to use a panel-data approach, which combines cross-sectional and time-series data. This means that the measurement period $T$ is shortened to allow multiple observations. This will add noise to the price processes. On the upside, the power of the testing will be increased through more observations. An advantage of using a panel is that we can allow for influences of non-convergence control factors in the form of unobservable individual country effects. This allows controlling for unspecified structural differences in price setting across the investigated countries.

A second weakness of $\beta$-convergence, and one that is shared by absolute and conditional convergence, is that all countries are assumed to converge at the same rate. This can be avoided by estimating (1') and (2) on time-series data individually for each country. Individual estimation (which in effect would be a unit-root test) requires data at higher frequency (monthly or quarterly data), which introduces more noise into the modeling. Also, it does not exploit the cross-sectional dependence between individual countries' price series. An alternative is to use seemingly unrelated regressions, which will explicitly take into consideration cross-sectional correlations among price series. Unfortunately, this will also greatly increase the number of parameters estimated, which will be detrimental to the power of the testing (Koedijk et al, 2004).

A third commonly used convergence measure is $\sigma$-convergence. It measures, as was previously mentioned, the dispersion of price levels in a group of countries. Price levels are converging if 
$\sigma_{t+T}<\sigma_{t}$

where $\sigma_{t}$ is the time $t$ standard deviation of $\log \left(p_{i, t}\right)$ across $i$. Countries will exhibit $\sigma$ convergence if they also exhibit absolute $\beta$-convergence; the opposite causality does not hold, though. As pointed out previously, we find evidence of $\sigma$-convergence in the transition from the pre to post euro period.

\section{Absolute $\beta$-convergence - Empirical Results}

To evaluate absolute $\beta$-convergence, we estimate ( $\left.1^{\prime}\right)$ over the full period and the two subperiods. Results are reported in Table 3. Since we are looking at cumulative price changes over the post euro period we are left with a small sample. To avoid bias from outliers, we make robust rank-based estimations as a complement to ordinary OLS. Columns (a) present estimates of (1') using OLS, while Columns (b) present estimates of (1') using OLS on ranked data.

\section{Insert Table 3 about here}

Irrespective of method used, manufacturing producer prices exhibit absolute $\beta$ convergence; all convergence parameters are significant both over the full period and in each sub-period. Using the OLS coefficient, the speed of convergence was about 3 percent per year over the full sample as well as in the pre euro period, and 6 percent per year in the post euro period. The difference in speed is not significant, however. Converting the $\beta$ s into $b \mathrm{~s}$, we can calculate half-lives of shocks to prices. The implied half-life in the post euro period is 11.6 years, whereas it is 24.5 years in the pre euro period. Both half-lives imply very slow rates of 
mean reversion compared to studies on consumer prices, which typically tend to find halflives of 3-5 years (see Kenneth Rogoff, 1996, for a review of evidence on absolute and relative law of one price). The rank-based estimations imply much faster half-lives of 2.3 years (post euro period) and 1.9 years. These half-lives are somewhat longer than the ones found by Parsley and Wei (2001), who find about 1 year for tradable goods, and Goldberg and Verboven (2004), who find about 1.3 years for automobiles.

\section{A. Robustness Checks}

For robustness, we perform two alternative robust estimations of (1), (i) robust nonparametric rank-based regressions based on the Wilcoxon score function, with intercepts estimated by the median of the residuals and (ii) least-absolute-deviations regressions. The results of both approaches confirm the results in Table 3 , with all $b$ s being significant. ${ }^{12}$

To increase the power of the testing, we increase the number of observations by using panels of yearly observations ( $T=1$ year) across all ten countries. Results of the panel regressions are reported in Columns (c). Using a panel increases the number of observations for each country, but also introduces more noise. Given the small size of our cross-section and the general lack of power in robust estimation, the increase in number of observations dominates. The conclusions are the same as for the long-low-frequency estimates in Columns (a) and (b) with significant convergence in both the full period and the two sub-periods. Speeds of convergence are similar to the ones found using rank-OLS estimations; implied half-lives are 3.3 years and 1.9 years in the post and pre euro periods. This difference is significant.

In the panel estimations we control for fixed country effects to account for any non-time country-specific price changes. In the full sample, this control does not add any explanatory value; the adjusted $R^{2}$ is even smaller after controlling for fixed country effects. In the two 
sub-periods the effect is much more marked with substantial increases in adjusted $R^{2} \mathrm{~s}$ and larger coefficient estimates. The levels of significance of estimated coefficients are not influenced, however. Controlling for fixed time effects (that is, controlling for unspecified structural yearly differences) increases adjusted $R^{2}$ in all samples, but yields nearly identical coefficients and levels of significance.

\section{Conditional $\beta$-convergence - Empirical Results}

To allow for a more complete specification of price developments, we now turn to testing conditional $\beta$-convergence. Due to lack of data, we have to restrict our testing to 1994-2004.

We have argued for several factors that could be expected to cause a link between the introduction of the euro and producer prices beyond price convergence, namely economic convergence and the B-S hypothesis, exchange-rate fluctuations and the existence of price rigidities, and the composition of each member country's effective, trade-weighted exchange rate. To test these potential explanations, we add growth in labor productivity in the manufacturing sector $(P R O D)$ to test the economic convergence hypothesis and changes in the nominal trade-weighted exchange rate $(N E E R)$ and, in the pre euro period, in the DC/ECU rate $(E C U)$ to test the importance of price rigidities. ${ }^{13}$

\section{A. Hypotheses}

Our hypotheses about the impact of our added variables on producer-price inflation in the transition to a common currency are the following. We expect a positive coefficient on $P R O D$, since according to the B-S hypothesis productivity increases would drive wages, which in turn would drive nontradables prices. If there were no price rigidities, foreign exporters would pass through exchange-rate changes. Then we would expect a negative coefficient on NEER in the post euro period (quoted indirectly as FC/DC, depreciations of the 
euro would be passed through to increasing sales prices). With price rigidities and full pricing-to-market, there would be no relationship between NEER and price changes. In the pre euro period, we include two exchange-rate variables (ECU and NEER). The marginal effect of $N E E R$ (after controlling for $E C U$ ) would range from -1 (no price rigidities) to 0 (full pricingto-market). The marginal effect of $E C U$ would instead range from -1 (full pricing-to-market, since we express prices in ECUs) to 0 (full pass-through).

\section{B. Results}

Figure 3 shows the bivariate relationships between cumulative price changes over the pre (Panels A and C) and post euro (Panels B and D) periods (up to December 2004) and (i) NEER (Panels A and B) and (ii) PROD (Panels C and D). Panel A shows a lack of relationship, which is consistent with complete market rigidities, while Panel B shows a negative relationship between NEER and prices. This is consistent with at least partial passthrough of exchange-rate changes and would indicate an increase in competition in the post euro period. The relationships between productivity changes and prices also differ between the two periods. There is no relationship in the pre euro period, while there is a negative relationship in the post euro period. This is in contrast to the positive relationship suggested by the B-S hypothesis. We see that one country (Ireland experienced no change in prices and growth of labor productivity of almost 60 percent) influences the slope of the relationship in the post euro period. This does not explain the negative relationship, however.

Insert Figure 3 about here 
To formally test conditional $\beta$-convergence, we estimate

(4) $\pi_{i, t, t+T}=\alpha+\frac{\left(1-e^{-\beta T}\right)}{T} \log \left(p_{i, t}\right)+\gamma_{1} \Delta_{t, t+T} N E E R_{i}+\gamma_{2} \Delta_{t, t+T} P R O D_{i}+\varepsilon_{i, t, t+T}$

where $\Delta_{t, t+T}$ denotes cumulative change between $t$ and $t+T$. Results for full-period changes are reported in Table 4 with OLS estimates in Columns (a) and rank OLS estimates in Columns (b).

There is support for conditional $\beta$-convergence in the full sample and, in particular, in the pre euro period, but not conclusively in the post euro period; in the post euro period, only estimations using OLS yield a significant $\beta$. Estimated speeds of convergence, using the OLS estimates in Columns (a), are 3 percent per year in the two sub-periods. For robustness, we perform non-parametric rank-based (Wilcoxon) regressions and least-absolute-deviations regressions of (4). They yield qualitatively similar results; the coefficient on convergence is significantly negative for all periods except for the full sample period in the least-absolutedeviations estimation. ${ }^{14}$

NEER is significant in both sub-periods, but not in the full sample. In line with Figure 3, coefficients are positive in the pre euro period, but negative in the post euro period. The negative coefficients in the post euro period suggest (at least partial) pass-through of exchange-rate changes. $P R O D$ is only significant in the post euro period, but with negative sign. In the non-parametric and least-absolute-deviations regressions, both NEER and PROD are significant in the post euro period and near significant in the full sample.

\section{Panel regressions}


To increase power of the testing, we estimate panel regressions of (4) on yearly price changes, allowing for fixed country effects. Here, we include $E C U$ in the pre euro period. In addition, we control for the following standard drivers of output prices. In a non-competitive market, increasing costs would be passed through to customers (cost-plus pricing). Labor is a major production factor in the manufacturing sector, motivating inclusion of labor costs as a control. We therefore include the growth in hourly compensation costs in the manufacturing sector $(H C C)$. We also include the country's output gap as calculated by the OECD, $(G A P)$, to control for the business cycle. Finally, we include beginning-of-period long-term (10-year government bond) interest rates (INT) to control for the impact of the cost capital due to the often heavy usage of fixed capital in the manufacturing sector. ${ }^{15}$ We expect positive coefficients on $H C C$ (increasing labor costs passed through to output prices) and GAP (increasing prices in times of expansion). Our expectations on INT is indeterminate (a negative coefficient could come from higher interest rates reduce investment activities and growth whereas a positive relationship could be caused by pass through of increasing interest costs)

Results are reported in Table 5. Again, there is strong support for conditional $\beta$ convergence, with significantly negative coefficients in all periods and irrespective of model specification. Implied half-lives are similar to prior estimations: 2.4-3.1 years (1.7-2.7 years) in the post (pre) euro periods.

NEER and PROD both turn out significant in the post euro period and with the expected signs. In the full model, we cannot reject full pass-through $\left(\gamma_{1}=-1\right)$ of NEER. This suggests that both the B-S and the inflation-import effects were at work during the post euro period. This is contrary to the pre euro period; NEER is significant in one model in the pre euro period, but with a positive coefficient, whereas $P R O D$ is insignificant. Results for the remaining three control variables are mixed. $H C C$ is significant and positive, as expected, in 
both periods, while GAP is significant only in the pre euro period. INT is significant in both periods, but with positive coefficients. This means that a high long-term interest rate at the beginning of the year leads to higher inflation during the year, which suggests that pass through of interest costs dominates the standard assumption of high interest rates being contractionary.

\section{Robustness checks}

To further check the robustness of the results, we test alternative specifications; results are presented in Table 6 for the full-period estimates. Ignazio Angeloni and Michael Ehrmann (2004) find a strong persistence in inflation developments. To test this, we add a one-year lag to inflation. The results in Column (a) show that this effect is not present in our data. As a second check, we lag all variables except the price level one year to allow for lags in price adjustments (Column (b)). The main consequences are that the significance of INT increases, while $H C C$ turns near significant. This suggests that there are lags in the responses to interest rates and changes in labor costs. This is perhaps not surprising, given multiplier effects of interest-rate changes and standard inflexibilities in wage negotiations. To test this further, we only lag $H C C$ and INT one year (Column (c)). The only consequence is that the significance of $H C C$ increases further. We also test this last model specification on the two sub-periods. In the post euro period, the primary effect is that the significance of INT disappears. In the pre euro period the significances of both $H C C$ and $I N T$ disappears.

\section{E. Decomposing the post euro period}

If we turn back to Figure 1 and look more closely at producer-price developments in the post euro period, we see that prices increased during the first two years and then stabilized. An even closer look at individual countries would have made this even more apparent. Inflation 
rates in the first two years for some countries reached levels not seen since the early 1980s. Annual inflation rates during the rest of the post euro period have instead been historically low, being at levels comparable to those just prior to the introduction of the euro.

Considering these patterns, can we see two phases in the post euro period? To investigate this, we divide our annual data into two groups, 1999-2000 and 2001-2004. Results from panel OLS regressions are reported in Table 6. For parsimony, we exclude GAP. Beginning with the first two years, the initial price level and $P R O D$ are significant. As for all other periods investigated, price convergence seems to be important, together with the B-S effect. Both these effects remain unchanged in the latter part of the post euro period, though with a slower speed of price convergence. In this part of the period, NEER also turns out significant and with an expected negative sign.

To summarize our findings as regards annual producer-price changes following the introduction of the euro, price convergence, productivity growth, and effective euro changes seem to drive producer prices in the euro zone. Exchange-rate effects were more important in the later years.

\section{$F$. The influence of the euro on producer prices}

Despite the short time period under investigation (six-seven years since the introduction of the euro) and thereby the fairly few data points available for the analysis we have - by using different techniques to mitigate that problem - found robust results as regards the relative inter-temporal influence from driving forces of producer-price developments. We find strong support for price convergence, both in an absolute and a conditional sense. We also find support for $\sigma$-convergence. We can safely say that producer prices are converging in the euro zone. 
Did the euro lead to increased price convergence? Not directly, since significances of absolute and conditional $\beta$ coefficients and speeds of convergence are similar before and after the introduction of the euro. The introduction as such does not seem to have influenced $\beta$ convergence. Prior studies of price developments in the euro zone have focused on dispersion in consumer prices. Among these, the three studies most resembling ours are Engel and Rogers (2004), Honohan and Lane (2003), and Rogers (2004). Honohan and Lane and Rogers find strong price-convergence effects in the post euro period, whereas Engel and Rogers do not. Honohan and Lane's and Rogers' results are as strong as ours.

Moving from testing absolute to conditional $\beta$-convergence does not influence estimated speeds of convergence, which must be interpreted as support for absolute $\beta$-convergence. In the extension this means that price levels are actually converging towards a common equilibrium. This is further strengthened by the fact that intercept terms (not reported) are constantly insignificant. The speed of convergence has been estimated to be around 3 percent, which suggests convergence over a 25-year period.

Productivity growth also has a significant impact on producer-price inflation. Looking at medium-term price changes (the cross-sectional estimations), productivity growth seems to influence prices negatively rather than positively as predicted by the B-S hypothesis. Rogers (2004) and Honohan and Lane (2003) find the same result for consumer prices after the euro introduction, but using yearly panel data. As they point out, several recent studies have found inverse relationships between productivity and prices. A negative coefficient suggests that countries that have seen the largest productivity increases have experienced the smallest price increases. Gianluca Benigno and Christoph Thoenissen (2003) suggest that firms that experience productivity increases can, under imperfect competition, reduce prices without affecting the profit margin, which would motivate a negative relationship. On the other hand, when testing on annual price changes, we find the expected positive relationship between 
productivity growth and inflation. This suggests that the B-S effect is at work at a yearly level, but not when reducing the periodicity. This divergence in relationships in the short and medium term is intriguing.

We also find support for Honohan and Lane's (2003) finding that the composition of the euro is asymmetric from an individual country viewpoint; the euro member countries' producer prices follow movements in the country's trade-weighted effective exchange rate. In line with Honohan and Lane, we interpret this as the import of inflation varying across countries.

The effects of productivity growth and effective exchange-rate changes differ significantly between the pre and post euro periods. The differences are consistent with what we would expect from the introduction of the euro, which suggests that the euro has influenced the behavior of producer prices. This could explain the increased dispersion in producer-price inflation we observe in the post euro period.

Looking at the panel results, productivity growth did not influence producer prices significantly in the pre euro period, whereas there is a significant positive effect in the post euro period. This is consistent with the B-S effect and the euro acting as a catalyst for increased economic convergence. This suggests that the relationship between productivity growth and producer-price inflation is temporary during the economic convergence period.

There is a notable change in the impact of effective exchange-rate changes on producer prices, with a significant and negative relationship between euro depreciations and producerprice increases in the post euro period. This suggests that pass through has increased in the transition to a common currency, which is as would be expected from increased price transparency. A direct consequence of increased price transparency is that the asymmetric effect of changes in the value of the euro is strengthened. This effect can be expected to remain as long as trade baskets differ across euro countries. 
Taking a closer look at the two most extreme countries in terms of price changes, Ireland and Portugal, is revealing. In January 1999, Ireland had the second highest producerprice level among the investigated countries, some 11 percent above the average. Our panel regressions suggest that this would have a dampening effect on Irish producer-price inflation. This is countered by the fact that Ireland experienced the highest productivity growth over the period, 8.3 percent per year, which is markedly above the sample average of 2.8 percent. The above-average growth in labor costs (highest in the euro zone) would also add to inflation, while the about average change in the effective exchange rate would not. Portugal, on the other hand, experienced an average of 4.7 percent inflation per year over the period. This is primarily explained by an initial low price level (third lowest in January 1999), since all other variables are close to the euro zone averages.

\section{Concluding remarks}

Our results may have profound policy implications for the current EU countries as well as for new countries considering the alternative of adopting a common currency. In the best of worlds, price convergence causing large and divergent producer-price increases could lead to a restructuring of the manufacturing sector in the euro zone. This would force firms to rationalize to stay competitive. Such beneficial developments would increase the competitiveness of the EU vis-à-vis the US and facilitate the achievement of the Lisbon agenda. The problem is that this process could be slow and painful (few countries can match the Irish example of exceptional productivity growth over a long stretch of years). Portuguese companies, for instance, face the risk of pricing themselves out of the market. Sticky wages and low levels of labor mobility, which are well-known problems in the euro zone, would mean that restructuring causes unemployment, in particular in the most affected countries. In this situation there is a considerable risk that exposed countries like Portugal will ask for the 
favor of being bailed out by the EU. An increased granting of structural support by the EU to the most affected countries or industries will hinder the restructuring. There is also a risk of increased competition among exposed member countries, like Portugal, for inward direct investments through social dumping and tax exemptions (Lars Oxelheim and Pervez Ghauri, 2004). Both scenarios will erode the role of the euro in fostering competition and would probably have an adverse effect on the future economic growth of the EU. To avoid these adverse scenarios it is important for policy makers in countries in the phase of transition to a common currency to know the driving forces at work in order to handle them adequately from a policy point of view. In particular, the detrimental effect of large swings in the value of the common currency on price convergence is important to keep in mind.

The implication of our results to policy on the EMU level is that asymmetric impacts of driving forces of producer-price inflation should be at least supervised, and at best moderated at the central-bank level with better control over inflation as measured by a wider price index than the consumer-price index and by an enhanced understanding at the national policy level of the inter-temporal distribution of effects of the driving forces as found in this study.

A topic for future research is the assessment of the gravity of the developments we have discussed. How large price gaps are sustainable under a single currency? Comparisons with the US could provide an answer, but are made impossible by the inexistence of producer-price data for US states. If price gaps are larger among countries in the euro zone than among states in the US, the euro zone with its markedly lower cross-border labor mobility will face difficulties. 


\section{REFERENCES}

Alterman, Bill. “Are Producer Prices Good Proxies for Export Prices?”, Monthly Labor Review, October 1997, 120(10), 18-32.

Angeloni, Ignazio and Ehrmann, Michael. "Euro Area Inflation Differentials", ECB Working Paper no 338, European Central Bank, 2004.

Antonucci, Daniele and Girardi, Alessandro. "Structural Changes and Deviations from the Purchasing Power Parity within the Euro Area", Applied Financial Economics, 2006, $16(1-2), 185-198$.

Barr, David; Breedon, Francis and Miles, David. "Life on the Outside. Economic Conditions and Prospects Outside Euroland", Economic Policy, 2003, 18(37), 573-613.

Baumol, William J. "Productivity Growth, Convergence, and Welfare: What the Long-Run Data Show", American Economic Review, 1986, 76(5), 1072-1085.

Bayoumi, Tamim and Eichengreen, Barry. "Ever Closer to Heaven? An OptimumCurrency-Area Index for European Countries", European Economic Review, 1997, 41(3-5), 761-770.

Beck, Guenter and Weber, Axel A. "How Wide are European Borders? On the Integration Effects of Monetary Unions", CFS Working Paper No 2001/07 - revised, Johann Wolfgang Goethe-Universität, Frankfurt, 2005.

Benigno, Gianluca and Thoenissen, Christoph. "Equilibrium Exchange Rates and Supply Side Performance”, Economic Journal, 2003, 113(486), C103-C124.

Bergstrand, Jeffrey H. "Structural Determinants of Real Exchange Rates and National Price Levels: Some Empirical Evidence”, American Economic Review, 1991, 81(1), 325-335.

Canzoneri, Matthew; Cumby, Robert; Diba, Behzad and Eudey, Gwen. "Productivity trends in Europe: Implications for Real Exchange Rates, Real Interest Rates, and Inflation", Review of International Economics, 2002, 10(3), 497-516. 
Devereux, Michael B; Engel, Charles and Tille, Cédric. "Exchange Rate Pass-Through and the Welfare Effects of the Euro", International Economic Review, 2003, 44(1), 223-242.

Engel, Charles and Rogers, John H. "How Wide is the Border?", American Economic Review, 1996, 86(5), 1112-1125.

Engel, Charles and Rogers, John H. "European Product Market Integration after the Euro", Economic Policy, 2004, 19(39), 347-384.

European Commission. The 1996 Single Market Review, 1996, Brussels.

European Commission. "EMU: The First Two Years", 2001, Euro Papers No 42, Brussels.

Foad, Hisham S. "Europe without Borders? The Effect of the EMU on Relative Prices", Department of Economics Working Paper No 05-15, Emory University, 2005.

Friberg, Richard. "Two Monies, Two Markets? Variability and the Option to Segment", Journal of International Economics, 2001, 55(2), 317-327.

Gadea, Maria-Dolores; Montañés, Antonio and Reyes, Marcelo. "The European Union Currencies and the US Dollar: from Post-Bretton-Woods to the Euro", Journal of International Money and Finance, 2004, 23(7-8), 1109-1136.

Goldberg, Pinelopi Koujianou and Knetter, Michael M. "Goods Prices and Exchange Rates: What Have We Learned?", Journal of Economic Literature, 1997, 35(3), 1243 1272.

Goldberg, Pinelopi Koujianou and Verboven, Frank. "Cross-Country Price Dispersion in the Euro Area: A Case Study of the European Car Market", Economic Policy, 2004, 19(40), 483-521.

Goldberg, Pinelopi Koujianou and Verboven, Frank. "Market Integration and Convergence to the Law of One Price: Evidence from the European Car Market", Journal of International Economics, 2005, 65(1), 49-73. 
Gros, Daniel and Niels Thygesen. European Monetary Integration, Harlow, UK: Prentice Hall, 1998.

Halpern, Laszlo and Wyplosz, Charles. "Equilibrium Exchange Rates in Transition Economies”, IMF Staff Papers, Working Paper No 96/125, 1997.

Helliwell, John F. “Do National Borders Matter for Quebec's Trade?”, Canadian Journal of Economics, 1996, 29(3), 507-522.

Honohan Patrick and Lane, Philip R. "Divergent Inflation Rates in EMU", Economic Policy, 2003, 18(37), 357-394.

Huang, Kevin X D and Liu, Zheng. “Inflation Targeting: What Inflation Rate to Target?", Journal of Monetary Economics, 2005, 52(8), 1435-1462.

Inklaar, Robert; O’Mahony, Mary; Robinson, Catherine and Timmer, Marcel. "Productivity and Competitiveness in the EU and the US", in O'Mahony, Mary and van Ark, Bart (editors), EU Productivity and Competitiveness: An Industry Perspective. Can Europe Resume the Catching-Up Process?, Luxembourg: Office for Official Publications of the European Communities, 2003.

Isgut, Alberto E. "Common Currencies and Market Integration across Cities: How Strong is the Link?”, in Alexander, Volbert; Mélitz, Jacques and von Furstenberg, George M (editors), Monetary Unions and Hard Pegs: Effects on Trade, Financial Development, and Stability, Oxford University Press, 2004.

Knetter, Michael M. “International Comparisons of Pricing-to-Market Behavior”, American Economic Review, 1993, 83(3), 473-486.

Koedijk, Kees G; Tims, Ben and van Dijk, Mathijs A. "Purchasing Power Parity and the Euro Area”, Journal of International Money and Finance, 2004, 23(7-8), 1081-1107. 
MacDonald, Ronald and Wójcik, Cezary. "Catching Up: The Role of Demand, Supply and Regulated Price Effects on the Real Exchange Rates of Four Accession Countries”, Economics of Transition, 2004, 12(1), 153-179.

McCallum, John. "National Borders Matter: Canada - US Regional Trade Patterns", American Economic Review, 1995, 85(3), 615-623.

Micco, Alejandro; Stein, Ernesto and Ordoñez, Guillermo. "The Currency Union Effect on Trade. Early Evidence from EMU”, Economic Policy, 2003, 18(37), 315-356.

Midelfart, Karen-Helene; Overman, Henry G. and Venables, Anthony J. "Monetary Union and the Economic Geography of Europe", Journal of Common Market Studies, 2003, 41(5), 847-868.

Mussweiler, Thomas and Strack, Fritz. "The Euro in the Common European Market: A Single Currency Increases the Comparability of Prices", Journal of Economic Psychology, 2004, 25(5), 557-563.

Neary, Peter. "Determinants of the Equilibrium Real Exchange Rate", American Economic Review, 1988, 78(1), 210-215.

O’Mahony, Mary. “Conversion Factors in Relative Productivity Calculations. Theory and Practice”, in Industry Productivity. International Comparison and Measurement Issues, OECD, 1996.

O'Mahony, Mary and van Ark, Bart (editors). EU Productivity and Competitiveness: An Industry Perspective. Can Europe Resume the Catching-Up Process?, Luxembourg: Office for Official Publications of the European Communities, 2003.

Obstfeld, Maurice and Rogoff, Kenneth. “The Mirage of Fixed Exchange Rates”, Journal of Economic Perspectives, 1995, 9(4), 73-97.

Obstfeld, Maurice and Rogoff, Kenneth. "New Directions for Stochastic Open Economy Models", Journal of International Economics, 2000, 50(1), 117-153. 
Oxelheim, Lars. Financial Markets in Transition - Globalization, Investment and Economic Growth, London: Routledge, 1996.

Oxelheim, Lars and Ghauri, Pervez (editors). European Union and the Race for Foreign Direct Investment in Europe, Oxford: Elsevier, 2004.

Parsley, David C and Wei, Shang-Jin. "Limiting Currency Volatility to Stimulate Goods Market Integration: A Price Based Approach”, NBER Working Paper Series, Working Paper No 8468, 2001.

Quah, Danny T. "Twin Peaks: Growth and Convergence in Models of Distribution Dynamics”, Economic Journal, 1996, 106(437), 1045-1055.

Rassekh, Farhad. "The Convergence Hypothesis: History, Theory, and Evidence”, Open Economies Review, 1998, 9(1), 85-105.

Rogers, John H. "Monetary Union, Price Level Convergence, and Inflation: How Close is Europe to the United States?", Board of Governors of the Federal Reserve System, International Finance Discussion Paper no 2002-740, 2004.

Rose, Andrew K. “One Money, One Market: The Effect of Common Currencies on Trade”, Economic Policy, 2000, 15(30), 7-33.

Rogoff, Kenneth. "The Purchasing Power Parity Puzzle”, Journal of Economic Literature, 1996, 34(2), 647-669.

Sala-i-Martin, Xavier X. "The Classical Approach to Convergence Analysis", Economic Journal, 1996, 106(437), 1019-1036.

Sinn, Hans-Werner and Reutter, Michael. "The Minimum Inflation Rate for Euroland“, NBER Working Paper No 8085, 2001.

van Ark, Bart. International Comparisons of Output and Productivity, 1993, Monograph Series No 1, Groningen: Groningen Growth and Development Centre. 
von Furstenberg, George M. "Price Insurance Aspects of Monetary Union", Journal of Common Market Studies, 2003, 41(3), 519-539.

Yang, Jiawen. "Pricing-to-Market in US Importers and Exporters. A Time Series and CrossSectional Study", Quarterly Review of Economics and Finance, 1998, 38(4), 843-861.

${ }^{1}$ Eleven countries joined on January 1, 1999 and Greece joined on January 1, 2001.

${ }^{2}$ For descriptions of data, see the next section.

${ }^{3}$ The flotation of the British pound, the Finnish markka, and the Italian lira in September 1992 marked the beginning of a period of large exchange-rate uncertainty that was not really resolved until the variation margins in the European Monetary System (EMS) was widened to \pm 15 percent in early August 1993.

${ }^{4}$ CPIs and not HICPs were used between August 1993 and December 1994 for Germany, Ireland, and Luxembourg.

${ }^{5}$ Excluding the two outliers in the post euro period, Ireland and Portugal, cuts the standard deviation in half, to 4.5 percent. These two countries are important, but do not fully explain the increased variability in producer prices.

${ }^{6}$ Barr et al (2003) refer the different results between the two studies to differences in sample periods; Barr et al, using data covering the period 1978-2002 find trade effects of the euro as early as in 1994, which they suggest could explain the smaller impacts found by Micco et al (2003), who use data for 1992-2002.

${ }^{7}$ For example, Tamim Bayoumi and Barry Eichengreen (1997) estimate that trade among the founding members of the EEC grew 3.2 percent per annum faster than predicted by the gravity model between 1956 and 1973. The European Commission (1996) estimated that the single market increased intra-EU trade in manufactured products by 20-30 percent between 1985 and 1995 .

${ }^{8}$ For a detailed exposition of productivity differentials in the manufacturing sector in the EU, see Robert Inklaar et al, 2003.

${ }^{9}$ Honohan and Lane (2003) show, for the years 2000-2001, that non-EMU imports as a percentage of total imports varied from 26 percent in Luxembourg to 79 percent in Ireland (the euro-zone average (standard deviation) was 49 percent (15 percent)). 
10 The euro did not exist before January 1999, which requires specifying a synthetic euro before that. We follow Eurostat in using the ECU as our synthetic euro, using data from Eurostat's NewCronos Database (table EURER_MO, series Euro/ECU exchange rates - monthly averages).

11 As further evidence of $\sigma$-convergence, the average monthly dispersion over the post euro period is significantly smaller than the average dispersion in the pre euro period.

${ }^{12}$ Estimated $b$ s using Wilcoxon-based estimation are $-0.059^{* * *},-0.047^{* *}$, and $-0.082^{* * *}$ in the full sample, pre, and post euro periods; estimated $b$ s using least-absolute-deviations regression are $-0.036^{* *},-0.030^{* *}$, and $-0.051^{*}$, in the same three periods.

${ }^{13} P R O D$ is (the log of) yearly labor productivity for the manufacturing sector from the European Commission $A M E C O$ Database (table Gross value added at 1995 prices per person employed: manufacturing industry). $E C U$ is (the $\log$ of) the monthly $\mathrm{DC} / \mathrm{ECU}$ rate from Eurostat. $N E E R$ is (the $\log$ of) monthly tradeweighted (based on export and import shares to the country's 41 main trading partners) effective exchange rates (each country's currency prior to the euro, in euro thereafter, from the Eurostat NewCronos database (table effrt_m), expressed as FC/EUR (ECU).

${ }^{14}$ Estimated $b$ s using Wilcoxon-based estimation are $-0.04^{* *},-0.03^{*}$, and $-0.04^{* * *}$ in the full sample, pre, and post euro periods; estimated $b$ s using least-absolute-deviations regression are $-0.02,-0.03^{* *}$, and $-0.03^{*}$ in the same three periods.

${ }^{15} \mathrm{HCC}$ is from the US Bureau of Labor Statistics report Hourly Compensation Costs for Production Workers in Manufacturing, 32 Countries or Areas, 22 Manufacturing Industries, 1992-2004; GAP is from the OECD Economic Outlook database (table Output gap), and INT is form the Eurostat NewCronos database (table mat_y10m). 
TABLE 1 - RELATIVE PRICE LEVELS IN THE EURO ZONE, 1997

\begin{tabular}{lllll}
\hline & UVR & ULC & HCC & EPPP \\
\hline Austria & 1.10 & 0.87 & 0.84 & 0.96 \\
Belgium & 0.90 & 0.85 & 0.86 & 0.90 \\
Finland & 0.94 & 0.77 & 0.83 & 1.01 \\
France & 0.97 & 0.85 & 0.66 & 0.99 \\
Germany & 1.00 & 1.00 & 1.00 & 1.00 \\
Ireland & 0.99 & 0.48 & 0.53 & 0.88 \\
Italy & 0.78 & 0.78 & 0.62 & 0.83 \\
Netherlands & 0.91 & 0.80 & 0.80 & 0.90 \\
Portugal & 0.80 & 0.81 & 0.20 & 0.60 \\
Spain & 0.77 & 0.86 & 0.47 & 0.75 \\
\hline
\end{tabular}

Notes: The table shows relative price levels for the euro zone members (excl Luxembourg) vs Germany for the year 1997. Relative UVRs are calculated from bilateral UVRs vis-à-vis the US. Relative unit labor costs (ULC) are calculated as labor compensation of employees in the manufacturing sector divided by value added at current prices in ECU. HCC is relative hourly compensation costs in the manufacturing sector. Expenditure PPPs are cross-rated from EPPPs vs the US.

Sources: UVRs from the University of Groningen International Comparisons of Output and Productivity database, labor compensation of employees and value added at current prices from the OECD STAN Structural Analysis database (tables LABR and VALU), HCCs from the US Bureau of Labor Statistics report Hourly Compensation Costs for Production Workers in Manufacturing, 32 Countries or Areas, 22 Manufacturing Industries, 1992-2004, and EPPPs from OECD Economic Outlook database. 
TABLE 2 - CUMULATIVE CHANGES IN PRODUCER PRICES (IN ECU AND EUR) IN THE PRE AND POST EURO PERIODS, AUGUST 1993 TO DECEMBER 2005

\begin{tabular}{lrlr}
\hline Austria & $14.0 \%(-1.2 \%)$ & Ireland & $1.0 \%(4.8 \%)$ \\
Belgium & $19.3 \%(3.2 \%)$ & Italy & $18.6 \%(6.7 \%)$ \\
Finland & $11.0 \%(8.6 \%)$ & Netherlands & $25.9 \%(0.2 \%)$ \\
France & $6.7 \%(2.9 \%)$ & Portugal & $32.9 \%(6.4 \%)$ \\
Germany & $11.3 \%(0.6 \%)$ & Spain & $20.8 \%(5.0 \%)$ \\
\hline Denmark & & & \\
Greece & $13.9 \%(9.5 \%)$ & Sweden & $7.4 \%(7.5 \%)$ \\
& $22.2 \%(9.3 \%)$ & UK & $12.9 \%(16.8 \%)$
\end{tabular}

Notes: The table shows annualized cumulative (log) producer-price changes in the EU countries over the pre (in parenthesis) and post euro periods.

Sources: Own calculations on data from OECD Main Economic Indicators Database (vol 2005, release 02, series 045K) and Eurostat's NewCronos Database (table EURER_MO, series Euro/ECU exchange rates - monthly data, period averages). 
TABLE 3 - ABSOLUTE $\beta$-CONVERGENCE IN THE EURO ZONE

\begin{tabular}{|c|c|c|c|c|c|c|c|c|c|}
\hline & \multicolumn{3}{|c|}{$93: 8-05: 12$} & \multicolumn{3}{|c|}{$99: 1-05: 12$} & \multicolumn{3}{|c|}{$93: 8-98: 12$} \\
\hline & (a) & (b) & (c) & (a) & (b) & (c) & (a) & (b) & (c) \\
\hline & OLS & Rank & Panel & OLS & Rank & Panel & OLS & Rank & Panel \\
\hline \multirow[t]{2}{*}{$\beta$} & -0.034 & -0.186 & -0.096 & -0.058 & -0.259 & -0.188 & -0.028 & -0.312 & -0.307 \\
\hline & $(-4.61)^{* \star *}$ & $(-7.83)^{\star \star \star}$ & $(-5.34)^{\star \star \star}$ & $(-3.32)^{* *}$ & $(-6.61)^{\star \star \star}$ & $(-9.07)^{\star \star \star}$ & $(-3.68)^{\star \star *}$ & $(-8.35)^{\star \star \star}$ & $(-12.4)^{\star \star \star}$ \\
\hline SE regr & 0.01 & 2.18 & 0.04 & 0.01 & 2.18 & 0.03 & 0.00 & 1.85 & 0.03 \\
\hline $\operatorname{Adj} R^{2}$ & 0.59 & 0.48 & 0.05 & 0.42 & 0.48 & 0.27 & 0.54 & 0.63 & 0.40 \\
\hline
\end{tabular}

Notes: ${ }^{*},{ }^{* *},{ }^{* \star}$ denote significance at the 10,5 , and 1 percent levels; $t$-statistics in parenthesis. Columns (a) contain nonlinear least squares estimates of (1'), Columns (b) robust rank-OLS estimates of (1'), and Columns (c) panel OLS estimates of (1') on yearly data allowing for fixed country effects. Sources: Producer prices are from the OECD Main Economic Indicators Database; price levels (UVRs) from the University of Groningen ICOP Database. 
TABLE 4 - CROSS-SECTIONAL ESTIMATES OF CONDITIONAL $\beta$-CONVERGENCE

IN THE EURO ZONE

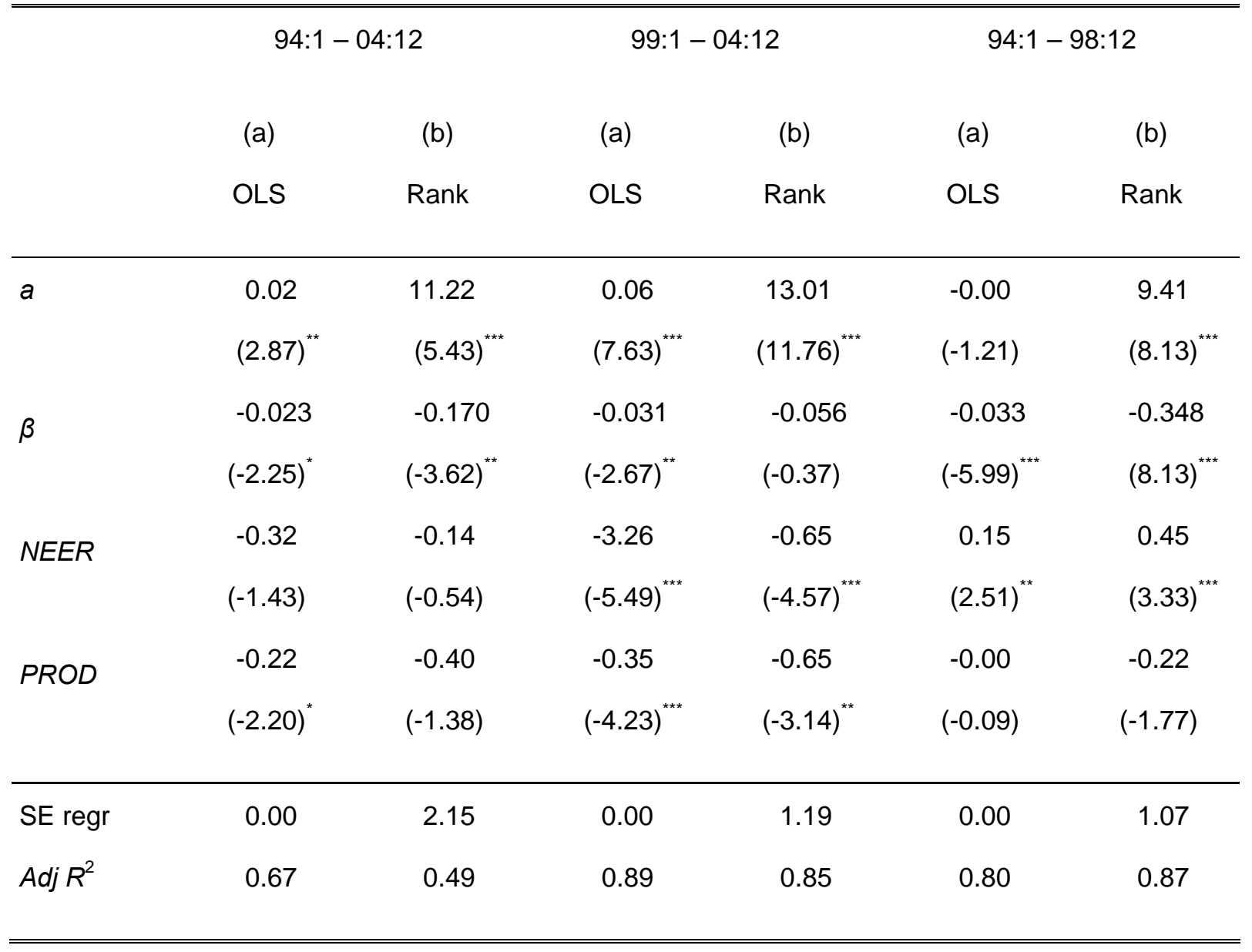

Notes: ${ }^{*},{ }^{* *},{ }^{* *}$ denote significance at the 10,5 , and 1 percent levels; $t$-statistics in parenthesis.

Columns (a) contain nonlinear least squares estimates of (4'), and Columns (b) robust rank-OLS estimates of (4').

Sources: Producer prices are from the OECD Main Economic Indicators Database; price levels (UVRs) from the University of Groningen ICOP Database; labor productivity is from the European Commission AMECO Database; nominal effective exchange rates are from the Eurostat NewCronos database. 
TABLE 5 - PANEL ESTIMATES OF CONDITIONAL $\beta$-CONVERGENCE IN THE

EURO ZONE

\begin{tabular}{|c|c|c|c|c|c|c|}
\hline \multirow[b]{2}{*}{$\beta$} & \multicolumn{2}{|c|}{$94: 1-04: 12$} & \multicolumn{2}{|c|}{$99: 1-04: 12$} & \multicolumn{2}{|c|}{$94: 1-98: 12$} \\
\hline & -0.117 & -0.141 & -0.200 & -0.250 & -0.343 & -0.210 \\
\hline & $(-6.06)^{* \star \star * t}$ & $(-8.63)^{k+* t}$ & $(-6.89)^{\star \star \star *}$ & $(-9.75)^{\star * \star *}$ & $(-12.19)^{\star * t *}$ & $(-3.79)^{* \star *}$ \\
\hline \multirow{2}{*}{ NEER } & -0.08 & -0.15 & -0.33 & -1.32 & 0.09 & 0.51 \\
\hline & $(-0.91)$ & $(-1.26)$ & $(-2.53)^{\star *}$ & $(-4.17)^{\star \star \star}$ & $(0.84)$ & $(2.81)^{* * \star}$ \\
\hline \multirow{2}{*}{$E C U$} & & & & & -0.43 & -0.34 \\
\hline & & & & & $(-3.71)^{\star \star \star *}$ & $(-2.88)^{\star \star \star}$ \\
\hline \multirow{2}{*}{ PROD } & 0.16 & 0.22 & 0.50 & 0.42 & -0.12 & 0.07 \\
\hline & (1.04) & (1.38) & $(3.10)^{* \star * x}$ & $(2.84)^{\star \star t *}$ & $(-0.67)$ & $(0.41)$ \\
\hline \multirow{2}{*}{$\mathrm{HCC}$} & & 0.07 & & 0.43 & & -0.21 \\
\hline & & (1.36) & & $(3.25)^{* * t}$ & & $(-2.10)^{* *}$ \\
\hline \multirow[t]{2}{*}{$G A P$} & & -0.01 & & 0.04 & & -0.53 \\
\hline & & $(-0.06)$ & & $(0.12)$ & & $(-1.82)^{\star}$ \\
\hline \multirow[t]{2}{*}{ INT } & & -0.04 & & 0.27 & & 0.10 \\
\hline & & $(-2.05)^{* *}$ & & $(3.27)^{\star \star * t}$ & & $(2.91)^{\star \star \star \star}$ \\
\hline SE regr & 0.04 & 0.04 & 0.03 & 0.02 & 0.03 & 0.03 \\
\hline $\operatorname{Adj} R^{2}$ & 0.10 & 0.14 & 0.58 & 0.65 & 0.55 & 0.65 \\
\hline
\end{tabular}

Notes: The table reports panel OLS estimates of (4) on yearly data allowing for fixed country effects; *, ${ }^{* *},{ }^{* \star *}$ denote significance at the 10,5 , and 1 percent levels; $t$-statistics in parenthesis.

Sources: Producer prices are from the OECD Main Economic Indicators Database; price levels (UVRs) from the University of Groningen ICOP Database; labor productivity is from the European Commission AMECO Database; nominal effective exchange rates are from the Eurostat NewCronos database. 
TABLE 6 - PANEL ESTIMATES OF CONDITIONAL $\beta$-CONVERGENCE IN THE EURO ZONE, ALTERNATIVE MODEL SPECIFICATIONS

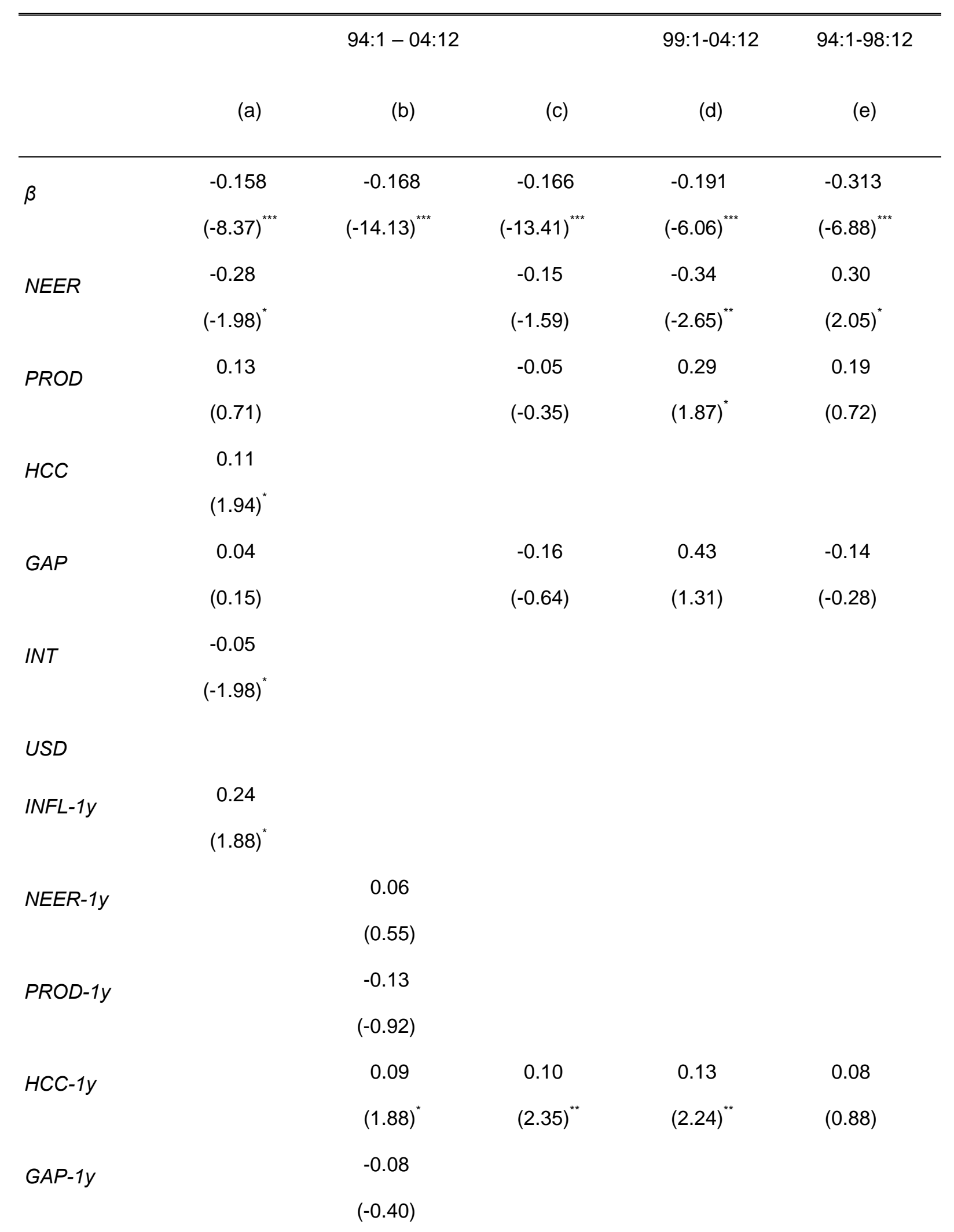




$\begin{array}{lllll}-0.09 & -0.09 & -0.04 & 0.07 \\ (-5.37)^{*+*} & (-5.24)^{* * *} & (-0.98) & (1.30)\end{array}$

$\begin{array}{ll}\text { ECU } & -0.29\end{array}$

$(-1.82)^{*}$

\begin{tabular}{llllll}
\hline SE regr & 0.04 & 0.03 & 0.03 & 0.02 & 0.03 \\
Adj $R^{2}$ & 0.17 & 0.36 & 0.37 & 0.66 & 0.49 \\
\hline
\end{tabular}

Notes: The table reports panel OLS estimates of (4) on yearly data allowing for fixed country effects; *, ${ }^{* *},{ }^{* \star *}$ denote significance at the 10,5 , and 1 percent levels; $t$-statistics in parenthesis.

Sources: Producer prices are from the SourceOECD Main Economic Indicators Database; price levels (UVRs) from the University of Groningen ICOP Database; labor productivity is from the European Commission AMECO Database; nominal effective exchange rates are from the Eurostat NewCronos database. 
TABLE 7 - PANEL ESTIMATES OF CONDITIONAL $\beta$-CONVERGENCE IN THE POST

\section{EURO PERIOD}

\begin{tabular}{lcc}
\hline \hline & $99: 1-00: 12$ & $01: 1-04: 12$ \\
\hline$\beta$ & -0.47 & -0.25 \\
NEER & $(-11.60)^{* * *}$ & $(-3.79)^{* * *}$ \\
& 1.24 & -1.64 \\
PROD & $(1.50)$ & $(-2.66)^{* *}$ \\
& 0.46 & 0.53 \\
$H C C$ & $(2.59)^{* *}$ & $(2.48)^{* *}$ \\
& -0.74 & 0.42 \\
INT & $(-2.28)^{*}$ & $(1.68)$ \\
& -0.19 & 0.22 \\
\hline SE regr & $(-1.36)$ & $(1.05)$ \\
Adj $R^{2}$ & 0.01 & 0.02 \\
\hline \hline
\end{tabular}

Notes: The table reports panel OLS estimates of (4) on yearly data; ${ }^{*},{ }^{* *},{ }^{* \star *}$ denote significance at the 10,5 , and 1 percent levels; $t$-statistics in parenthesis.

Sources: Producer prices are from the SourceOECD Main Economic Indicators Database; price levels (UVRs) from the University of Groningen ICOP Database; labor productivity is from the European Commission AMECO Database; nominal effective exchange rates are from the Eurostat NewCronos database. 


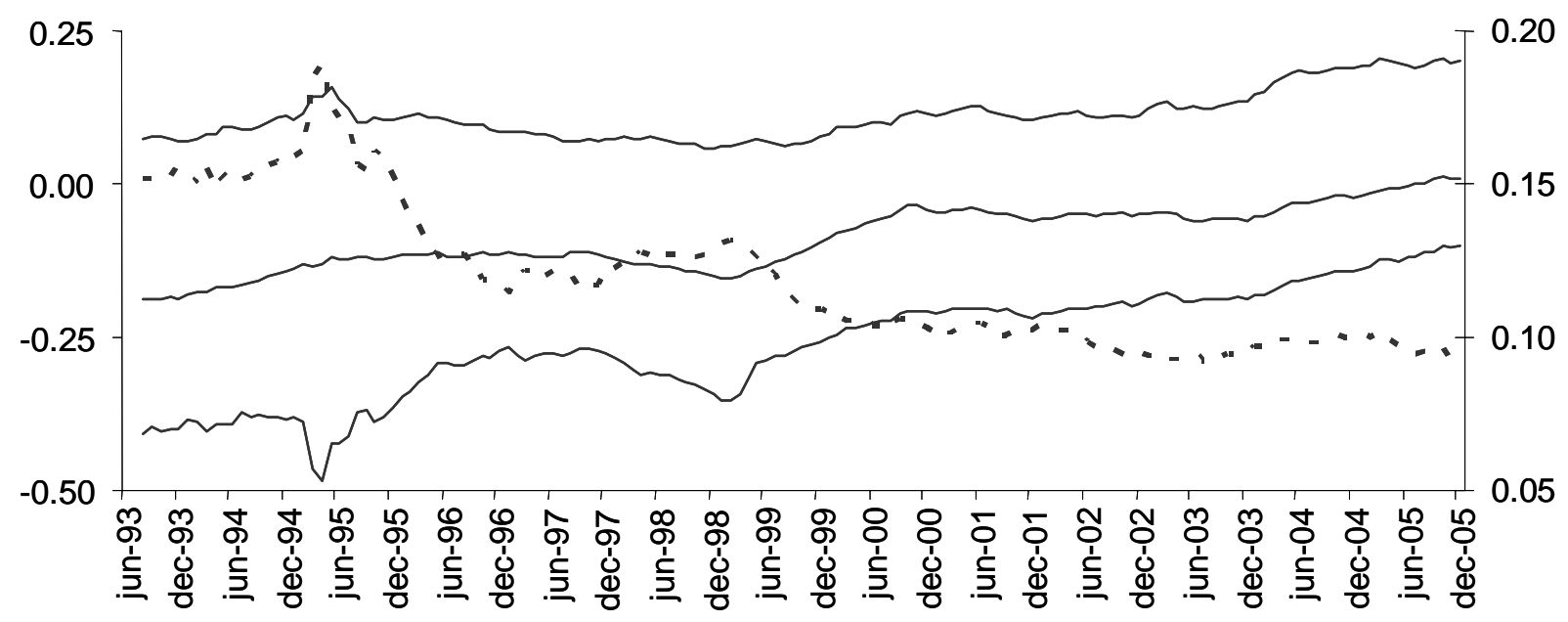

FIGURE 1. DISPERSION IN PRODUCER PRICES, AUGUST 1993 TO DECEMBER 2005

Notes: The table shows minimum, mean, and maximum (solid lines) producer prices in EUR (ECU before 1999) in the euro zone (all original members excl Luxembourg) rebased on UVRs for 1997 (left axis). It also shows the standard deviation (dashed line) of price levels (right axis) across the ten investigated countries.

Sources: Own calculations on data from University of Groningen International Comparisons of Output and Productivity database, OECD Main Economic Indicators Database (vol 2005, release 02, series 045K), and Eurostat's NewCronos Database (table EURER_MO, series Euro/ECU exchange rates monthly data, period averages). 


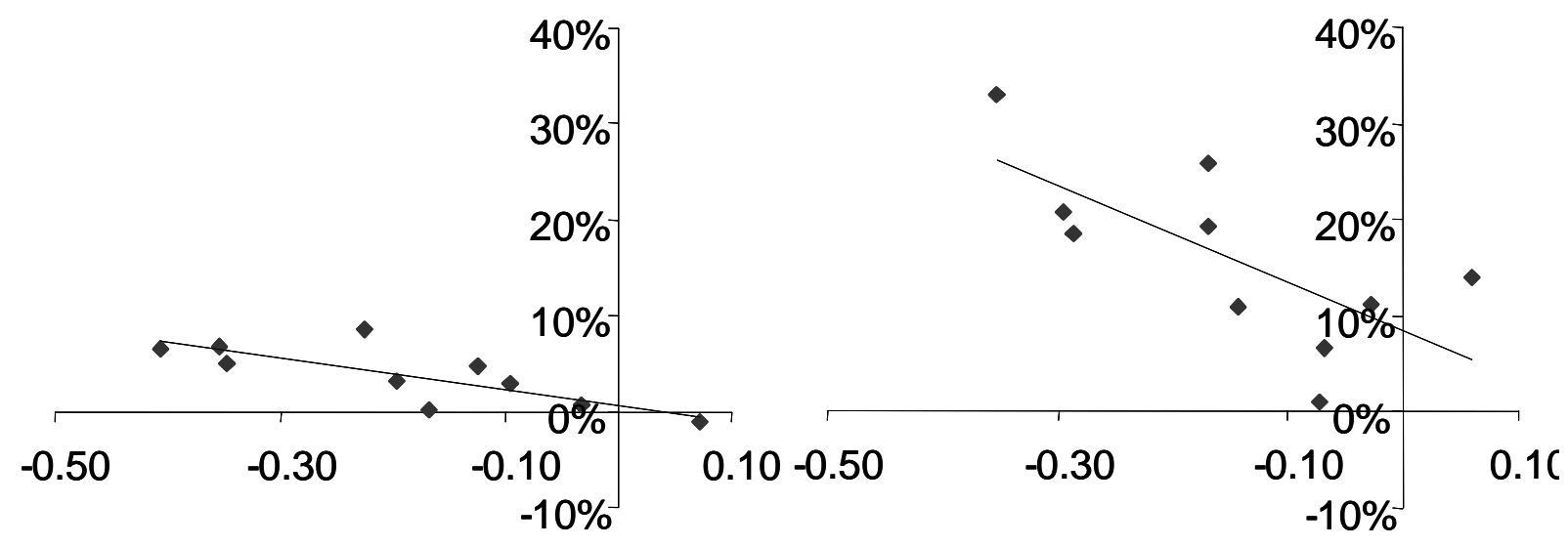

FIGURE 2 RELATIONSHIP BETWEEN CUMULATIVE PRICE CHANGES AND

INITIAL PRICE LEVELS

Notes: X-axis: initial price level; Y-axis: cumulative producer-price change in the manufacturing sector; all data in logs.

Sources: Producer prices are from the OECD Main Economic Indicators Database; price levels (UVRs) from the University of Groningen ICOP Database. 
Panel A Effective exchange rates

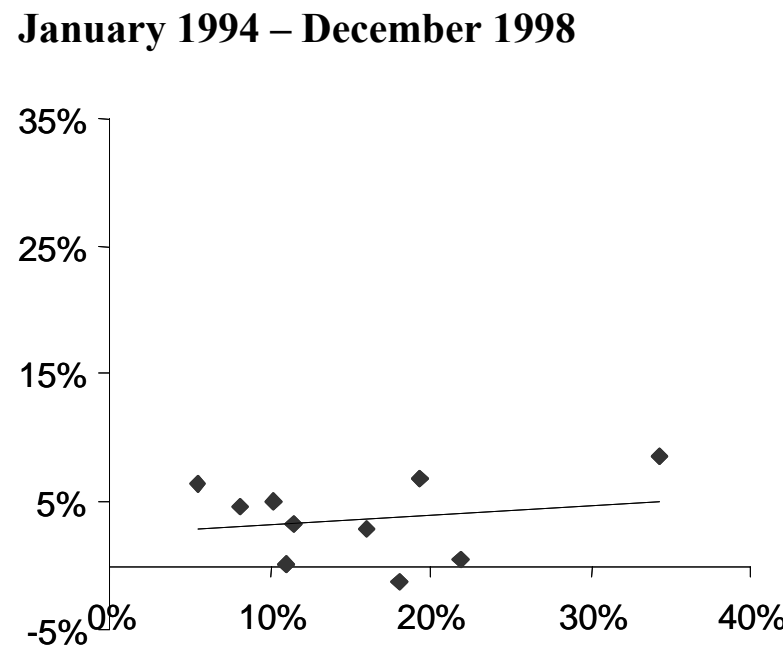

Panel C Productivity growth January 1994 - December 1998

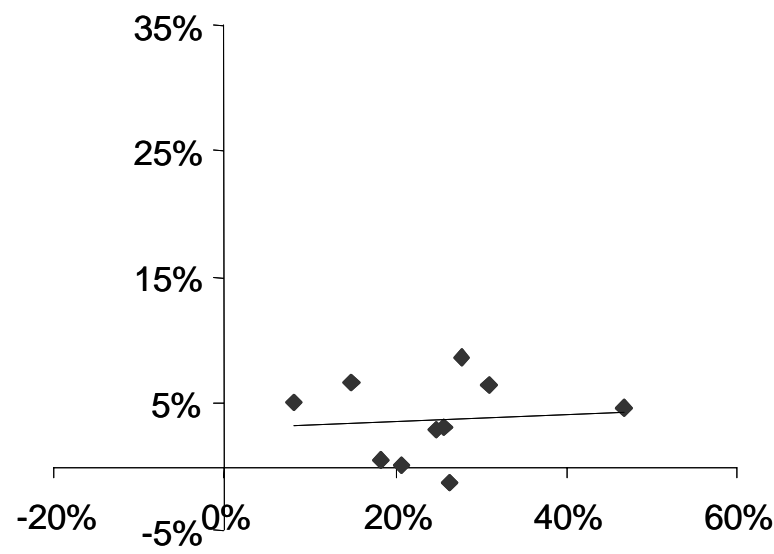

Panel B Effective exchange rates
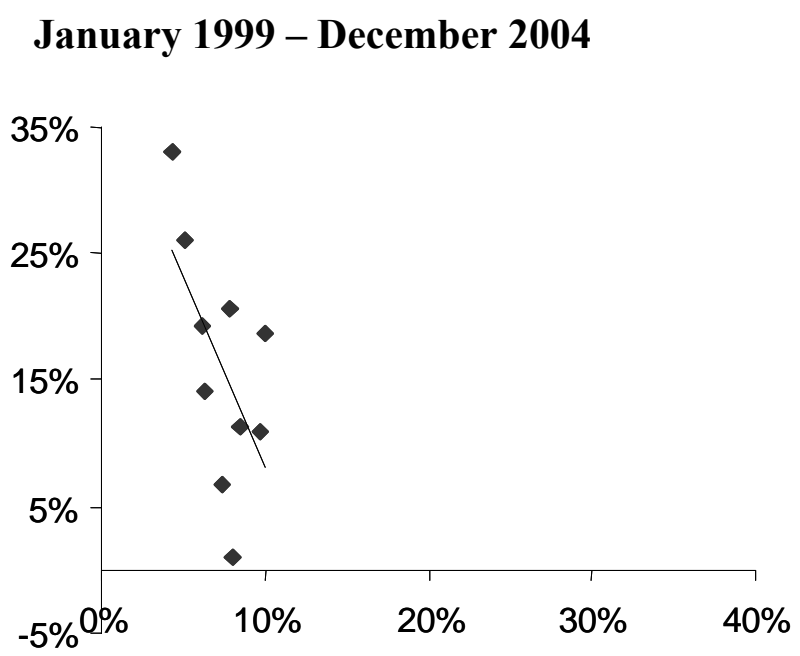

Panel D Productivity growth January 1999 - December 2004

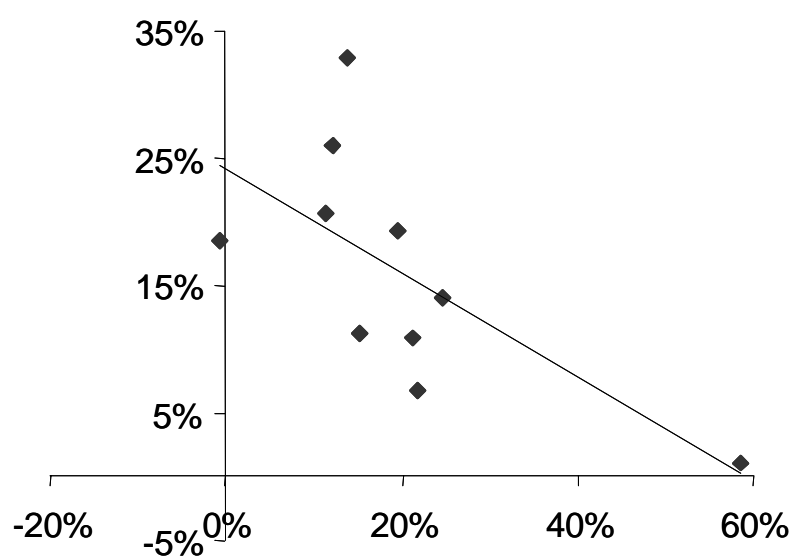

FIGURE 3. RELATIONSHIPS BETWEEN CUMULATIVE PRICE CHANGES, PRODUCTIVITY GROWTH AND EFFECTIVE EXCHANGE RATES

Notes: X-axis: cumulative changes in nominal effective trade-weighted exchange rate (Panels $\mathrm{A}$ and B) and labor productivity (Panels C and D); Y-axis: cumulative producer-price change in the manufacturing sector.

Sources: Producer prices are from the OECD Main Economic Indicators Database; price levels (UVRs) from the University of Groningen ICOP Database; labor productivity is from the European Commission AMECO Database; nominal effective exchange rates are from the Eurostat NewCronos database. 
